\title{
El embarazao
}

por Isabel Crooke Ellison

El secreto para ser aceptado como médico en una población rural, es hacerse amigo del curandero o brujo de la comunidad. Sólo entonces, la gente comienza a buscar sus consejos. Por lo tanto, recién llegada a Barichara, averigüé quién era el médico del pueblo y muy pronto salí al campo a buscar a don Luis para presentarme.

-Buenos días, don Luis, yo soy...

—Sí, ya sé, ya me hablaron de usté. Mucho gusto dotora. Y bienvenida.

Y no se necesitó más.

Luego de varias semanas de haber abierto consulta, una mañana aparecieron tres mujeres campesinas, una ya mayor, las otras más jóvenes: Doña Helena y sus hijas, como supe luego. Les hice las preguntas iniciales de rutina:

— ¿Quién viene a consulta? - y — ¿Qué le pasa?

Pero la respuesta de la señora fue muy enigmática.

-No dotorcita, es que nos mandó don Luis. Él piensa que usted podría ayudarnos mejor que él. Es que mi marido está en estado.

—¿En estado? ¡Embarazado!

-Como usté lo dice dotorcita, embarazao...

Y esta es otra cosa que uno tiene que aprender: nunca sonreírse y mucho menos reírse de las repuestas de los aquejados como, por ejemplo, hombres con un viento en la vagina; mujeres con problemas del prostábulo o corazones incubados.

— ¿Y por qué creen ustedes que está embarazado?

-Oh dotorcita, porque tiene casi nueve meses de embarazo.

-Pero tú sabes que los hombres no se embarazan.

-Ay doctorcita, pero sí cuando los endemonian. Está embrujado.

— ¿Pero quién y cuándo lo embrujó?

-Ay dotorcita, pasó cuando se fue p'a trabajar en una finca en Venezuela. Tuvo una pelea con un tipo y usté sabe que esos llaneros son terribles, son puros brujos. Poco despuecito, el patrón se enfermó. Le empezó a crecer la panza y, al fin, no pudo trabajar más. Regresó a Barichara, a la casa muy mal con el estógamo enorme. No le digo, ya debe tener casi los nueve meses.

Al preguntarle por qué no lo había llevado al hospital: 
- ¡Dotorcita, cómo se le ocurre! ¡Cómo vamos a decirle al doctor del hospital que mi marido está embarazao! Esa gente no entiende... pero don Luis dijo que usté sí.

$\mathrm{Al}$ terminar un interrogatorio exhaustivo, supe que el enfermo no era más que un montón de piel y huesos y, en la mitad, una enorme barriga. Ya no comía y que:

-En cualquier momento se le va a estallar ese estógamo y saldrá el fenómeno y él se morirá. ¡Ay dotorcita, qué voy hacer, qué hago!

¡Qué dilema! ¿Qué podía hacer? Ya tenía una imagen muy clara de un paciente en los últimos momentos de un cáncer gastrointestinal.

- Bueno, de todos modos tendré que verlo y posiblemente ustedes tendrán que llevarlo al hospital para que le tomen una radiografía.

Unos tres días más tarde estuve caminando por sendas pastoriles con las dos hijas. Al llegar a la casa, una pintoresca vivienda campestre llena de materas vivas de color, fui recibida por numerosos miembros de la familia, los hombres tomando cerveza en el patio. Fui invitada con una pola:

-Échese un traguito doctorcita.

Y mucho antes de poder revisar al enfermo, tuve que escuchar las diferentes explicaciones del triste fenómeno que acosaba al pobre don Juan, y bajar unas cervezas más. Al fin, vi frente a mí una figura postrada, definitivamente con una pata al otro lado. Sin embargo, al tocar el abdomen, sólo encontré un enorme balón de gases. Pude convencer a la familia que con una orden mía, en el hospital, le tomarían los rayos $\mathrm{X}$ sin ninguna pregunta.

Pocos días más tarde, tenía las placas en mis manos y, como anhelaba mi alma, no se veía más que el colon totalmente inflado, seguramente invadido por amebas y otras canallas parasíticas. Sin embargo, la familia no aceptaría el diagnóstico. Don Juan estaba embarazado. Yo tendría que mostrarles el feto, ese fenómeno de la nigromancia. Afortunadamente, se quedaron satisfechos al enseñarles una mancha muy oscura en un rincón de la placa. Sin embargo, la vida del pobre don Juan colgaba de un hilo. Podría partirse en cualquier momento.

-Doña Helena, lo que tendremos que hacer ahora es darle mucha medicina para tratar de matar al feto brujo antes de que se le pudra toda la tripa a su marido. Ustedes tienen que entender que las esperanzas de que sobreviva son escasas. Ha pasado demasiado tiempo.

Estalló una contienda de acusaciones y quejas hasta que, al fin, salieron del consultorio con las instrucciones y medicamentos necesarios para comenzar una larga batalla con las esperanzas de ganarla. Y la ganamos. 
Pero esto no es el fin del cuento. Unas semanas más tarde, apareció en el consultorio un campesino bastante hosco. A las preguntas de siempre, me contestó de mal genio:

— ¡Me están robando la yuca!

-Perdón ¿la que?

- iLa yuca, la yuca, la comida!

-Cómo lo siento, pero ¿qué le pasa a usted? ¿Por qué viene a verme?

-Por eso. Que me descubra quién es el culpable, quién me está robando. Me dijeron que usté es una adivina, que puede descubrir las cosas.

-Oh no señor, qué pena. Puedo adivinar las enfermedades del cuerpo, pero nada más.

El señor me lanzó una mirada asesina, se levantó y salió.

Con eso, se acabó mi fama de bruja. 